\title{
Perbandingan Teori 4 Dimensi Keagamaan (4BDRS) dan Teori Tahapan Iman Fowler untuk Riset Psikologi Agama di Indonesia:
}

\section{Perbedaan, Perkembangan Terkini, dan Implikasi}

\author{
Lindawati $^{1}$, Ihan Martoyo ${ }^{2,3 a}$ \\ ${ }^{1}$ Pendidikan Agama Kristen, Universitas Pelita Harapan, Tangerang, Indonesia \\ ${ }^{2}$ Teknik Elektro, Universitas Pelita Harapan, Tangerang, Indonesia \\ ${ }^{3}$ Sekolah Tinggi Teologi Reformed Indonesia \\ a ihan.martoyo@uph.edu
}

Comparison of 4 Basic Dimension of Religiousness Scale Manuscript type: Literature Review (4BDRS) and Fowler's Stages of Faith for Psychology of Religion Research in Indonesia:

Differences, Recent Updates, and Implications

\begin{abstract}
A lot of studies in psychology of religion have been conducted in Indonesia, however not many used tested theoretical frameworks. In this short review, two theories that are growing in international research and received considerable attention in psychology of religion studies in Indonesia, will be surveyed and compared. The 4 Basic Dimensions of Religiousness Scale (Saroglou) provides a multidimensional approach to religiousness that involves the aspects of: (1) Cognitive (Believing), (2) Affective (Bonding), (3) Behavior, and (4) Community (Belonging). On the other side, Fowler's Stages of Faith offers a framework to discuss the psychological structure that becomes the vessel for religious manifestation at a certain faith stage apart from the content of a specific faith. This survey and comparison will help provide options for more systematic research on psychology of religion with a more tested theoretical
\end{abstract}

Article history:

Received: 15 November 2021

Accepted: 22 Februari 2022

Available online: 08 Maret 2022

\section{Keywords:}

Dimensions of religiousness

Indonesia

Religiosity

Stages of Faith framework in Indonesia.

\section{Abstrak}

Banyak usaha penelitian psikologi agama di Indonesia sudah dilakukan, namun sedikit studi yang berlandaskan suatu teori yang cukup teruji. Dalam review singkat ini, dua teori yang berkembang dalam penelitian internasional dan memperoleh cukup banyak perhatian dalam penelitian psikologi agama di Indonesia akan disurvei dan diperbandingkan. Teori 4 Dimensi Keagamaan (Saroglou) menyediakan pendekatan multidimensi terhadap keagamaan, yang melibatkan aspek: (1) Kognitif (Kepercayaan), (2) Afektif (Ikatan emosional), (3) Perilaku (Tindakan), dan (4) Komunitas (Kebersamaan). Di sisi lain, Teori Tahapan Iman dari James Fowler memberikan kerangka untuk mendiskusikan struktur jiwa yang menjadi wadah manifestasi iman pada tahapan perkembangan jiwa tertentu yang terlepas dari konten iman yang spesifik. Survey dan perbandingan ini akan menolong memberikan pilihan untuk penelitian psikologi agama yang lebih sistematis dengan kerangka teori yang lebih teruji di Indonesia.

Kata Kunci: Dimensi Keagamaan, Indonesia, Religiositas, Tahapan Iman 


\section{PENDAHULUAN}

Penelitian dalam bidang psikologi agama memang sering mendapatkan tantangan karena sikap yang saling mencurigai antara bidang psikologi dan bidang agama. Misalnya, Sigmund Freud - bapak psikoanalisis - dikenal menganggap agama sebagai proyeksi kebutuhan anak-anak terhadap perlindungan ayahnya yang berlanjut terus pada orang dewasa. Lebih jauh, Freud menganggap agama sebagai sebuah neurosis obsesi universal (Storr, 2001). Akibatnya, sebagai reaksi, kalangan agama sering mencurigai psikologi sebagai bidang ilmu yang memicu pikiran ateistis. Susabda (2020) menyampaikan bahwa ada kelompok teolog yang tetap menolak dan memusuhi psikologi karena prejudice dan kesalahmengertian (Susabda, 2020).

Terlepas dari perdebatan tersebut, Indonesia justru sebenarnya menyediakan peluang yang besar untuk penelitian dalam bidang psikologi agama. Menurut survey Pew Research Center (Poushter, Fetterolf, \& Tamir, 2019), 83\% orang Indonesia menganggap agama memainkan peranan yang lebih penting dibandingkan 20 tahun yang lalu, namun di sisi lain, 80\% orang Indonesia juga merasakan meningkatnya diversitas agama di negaranya. Dengan demikian, Indonesia sebenarnya menyediakan suatu laboratorium yang sangat besar untuk penelitian dalam bidang religiositas dan psikologi agama, terutama dalam konteks keberagaman agama.

Namun sayangnya, studi tentang psikologi agama di Indonesia diamati sering dilakukan tanpa berlandaskan teori yang teruji dan umumnya menggunakan skala yang dibuat sendiri (El Hafiz \& Aditya, 2021). Akibatnya terdapat kebutuhan ulasan mengenai teori dan instrumen yang telah teruji dan lebih sistematis untuk diterapkan pada studi yang lebih produktif. Dalam Artikel singkat ini dipilih dua buah teori yang telah diuji dan berkembang dalam penelitian di berbagai negara, dan juga mendapatkan perhatian dalam berbagai riset di Indonesia, yaitu teori 4-Dimensi Keagamaan (4 Basic Dimensions of Religiousness Scale), sering disingkat 4BDRS dari Saroglou (2011), dan Teori Tahapan Iman (Stages of Faith) dari Fowler (1981). Teori 4BDRS menyediakan tinjauan teoretis terhadap religiositas secara multidimensi, sehingga lebih lengkap dibanding hanya menyoroti satu dimensi, misalnya hanya dimensi kognitif atau kelakuan saja. Teori Fowler menjanjikan satu tinjauan teoretis yang memungkinkan untuk bicara soal "kedewasaan" iman yang muncul dalam berbagai tahapan. Kedua teori ini, dalam tingkat yang berbeda, sudah juga diteliti di Indonesia, sehingga berpotensi disurvey dan dibandingkan di sini.

Dalam mendiskusikan kedua teori tersebut, pembahasan akan difokuskan kepada berbagai aplikasi teori yang telah dilakukan di berbagai negara, perkembangan penggunaan teori tersebut dalam penelitian di Indonesia, serta kekuatan/kelemahan yang muncul dalam telaah perbandingan kedua teori tersebut. Analisis dan perbandingan yang dilakukan di sini akan memberikan pilihan untuk penelitian yang lebih sistematis dengan teori yang teruji untuk Indonesia. Analisis singkat tentang kedua teori juga akan memberikan gambaran umum tentang ruang riset lebih lanjut, sehingga dapat membuat penelitian psikologi agama di Indonesia lebih bergairah.

\section{Teori 4-Dimensi Keagamaan}

Berbeda dari berbagai teori religiositas yang hanya mencermati satu bagian dari keagamaan, misalnya perilaku terkait ritual tertentu atau konsep doktrinal tertentu, Teori 4BDRS menyajikan pendekatan multidimensi terhadap keagamaan, yang meliputi aspek Believing, Bonding, Behaving dan Belonging. Kepercayaan (Believing) merepresentasikan dimensi konseptual kognitif dari keagamaan. Walaupun setiap agama dapat mempunyai pemahaman yang partikular, namun ada bagian yang secara universal menjadi bagian dari setiap agama, yaitu kepercayaan kepada eksistensi transenden di luar manusia, yang menentukan tujuan hidup dan pemaknaan hidup. Bonding mewakili dimensi afektif atau ikatan emosional dari keagamaan. Ikatan emosional kepada yang transenden ini dapat dirasakan melalui berbagai ritual keagamaan yang dijalani, yaitu doa, meditasi, penyembahan 
Indonesia Journal for The Psychology of Religion (2021), 1(2), 79-96

dan ziarah. Dimensi Behaving atau perilaku dalam keagamaan sering terkait dengan standar moral untuk membedakan yang benar dan yang salah dari sudut pandang agama. Dimensi Belonging, yaitu menjadi bagian pada komunitas orang percaya tertentu, mewakili aspek sosial dari keagamaan, yang dapat memberikan kohesivitas dan identitas pada sekelompok orang beriman.

Selain sifatnya yang multidimensi, skala teori 4BDRS tidak mengacu pada agama tertentu, sehingga dapat berlaku untuk berbagai agama. Setiap dimensi dari skala 4BDRS terdiri dari tiga butir pertanyaan dengan total 12 pertanyaan (lihat Tabel 1). Terlihat bahwa setiap butir pertanyaan tidak menanyakan praktik partikular agama tertentu, melainkan menyasar aspek yang universal dari keagamaan dalam 4 dimensi dasar tersebut.

Tabel 1.

\section{Versi 4-BDRS dalam bahasa Indonesia}

Petunjuk Pengisian: Anda mungkin tertarik atau tidak tertarik dengan agama karena berbagai alasan. Cobalah untuk se-spesifik mungkin dalam jawaban anda tentang pertanyaan-pertanyaan di bawah ini tentang alasan-alasan anda tertarik pada agama.

\begin{tabular}{|c|c|c|c|c|c|c|c|c|}
\hline No & & $\begin{array}{c}\text { Sangat } \\
\text { tidak } \\
\text { setuju }\end{array}$ & & & & & & $\begin{array}{l}\text { Sangat } \\
\text { setuju }\end{array}$ \\
\hline 1 & $\begin{array}{l}\text { Saya merasa terikat dengan agama karena agama membantu saya untuk menemukan } \\
\text { tujuan hidup }\end{array}$ & 1 & 2 & 3 & 4 & 5 & 6 & 7 \\
\hline 2 & $\begin{array}{l}\text { Adalah penting untuk mempercayai kekuatan yang lebih tinggi yang memberikan arti } \\
\text { bagi keberadaan manusia }\end{array}$ & 1 & 2 & 3 & 4 & 5 & 6 & 7 \\
\hline 3 & $\begin{array}{l}\text { Kepercayaan agama memiliki pengaruh yang penting bagi pemahaman kita mengenai } \\
\text { keberadaan manusia }\end{array}$ & 1 & 2 & 3 & 4 & 5 & 6 & 7 \\
\hline 4 & Saya menyenangi upacara-upacara keagamaan & 1 & 2 & 3 & 4 & 5 & 6 & 7 \\
\hline 5 & $\begin{array}{l}\text { Ritual, aktivitas, ataupun kegiatan keagamaan membuat saya merasakan emosi yang } \\
\text { positif }\end{array}$ & 1 & 2 & 3 & 4 & 5 & 6 & 7 \\
\hline 6 & Agama memiliki banyak seni, ekspresi, dan simbol yang saya nikmati & 1 & 2 & 3 & 4 & 5 & 6 & 7 \\
\hline 7 & Saya terikat pada agama oleh karena nilai-nilai dan etika yang diberikannya & 1 & 2 & 3 & 4 & 5 & 6 & 7 \\
\hline 8 & Agama membantu saya untuk berusaha hidup secara bermoral & 1 & 2 & 3 & 4 & 5 & 6 & 7 \\
\hline 9 & Ketika saya menghadapi dilema moral, agama membantu saya untuk membuat keputusan & 1 & 2 & 3 & 4 & 5 & 6 & 7 \\
\hline 10 & Saya menikmati tergabung di dalam suatu kelompok/komunitas keagamaan & 1 & 2 & 3 & 4 & 5 & 6 & 7 \\
\hline 11 & $\begin{array}{l}\text { Terlibat dalam tradisi keagamaan dan mengidentifikasikan diri dengan tradisi tersebut } \\
\text { adalah penting bagi saya }\end{array}$ & 1 & 2 & 3 & 4 & 5 & 6 & 7 \\
\hline 12 & Merujuk pada tradisi keagamaan adalah penting bagi identitas budaya/etnis saya & 1 & 2 & 3 & 4 & 5 & 6 & 7 \\
\hline
\end{tabular}

Teori 4BDRS juga sudah diuji dan diterapkan dalam berbagai agama dan negara dan dihubungkan dengan berbagai konstruk psikologis lainnya. Berbagai artikel penting dari berbagai negara dan Indonesia beserta kesimpulan yang dihasilkan akan dianalisis dalam artikel ini. Kajian tersebut diharapkan memberikan gambaran umum dan membuka jalan pada kemungkinan arah penelitian berikutnya di Indonesia. Tabel 1 menunjukkan skala 4-BDRS yang telah melewati terjemahan dan uji terjemahan balik, serta melewati uji faktorial dan uji invariance (Aditya, Martoyo, et al., 2021). Pengembangan penelitian dengan skala ini dilakukan di Indonesia dengan komunikasi dan persetujuan Saroglou.

\section{Teori Tahapan Iman}

Dengan memadukan teori perkembangan kognitif (Piaget), psikososial (Erikson), dan 
perkembangan moral (Kohlberg), serta melakukan 359 interview dari tahun 1972 sampai 1981, Fowler (1981) mengembangkan teori perkembangan tentang religiositas. Walaupun Fowler sendiri juga adalah seorang pendeta Metodis, teori perkembangan yang dia ajukan lebih berhubungan dengan cara seseorang melakukan konstruksi "realitas sejati" daripada konten spesifik agama tertentu (Leak, Loucks \& Bowlin, 1999). Fowler merumuskan perkembangan tahapan iman yang bergerak melewati tahap: (0) Undifferentiated faith, (1) Intuitive-Projective Faith, (2) Mythic-Literal Faith, (3) Synthetic Conventional Faith, (4) Individuative-Reflective Faith, (5) Conjunctive Faith dan (6) Universalizing Faith.

Empat tahapan pada rentang tengah teori Fowler biasanya dianggap lebih menarik karena mengekspresikan struktur jiwa untuk iman anak-anak (Mythic-Literal Faith), iman remaja (Synthetic Conventional Faith), iman dewasa (Individuative-Reflective Faith), dan iman yang matang (Conjunctive Faith). Iman anak-anak ditandai dengan pola pikir sederhana hukum timbal balik, perbuatan baik akan mendapat hadiah, sedangkan perbuatan buruk akan dihukum (Fowler, 1991). Selain itu, pola pikir keimanan banyak dilakukan dengan narasi pada tahapan iman anak-anak. Tahapan iman remaja sudah ditandai dengan berkembangnya relasi interpersonal, namun belum terbentuk perspektif orang ketiga yang secara obyektif dapat melakukan evaluasi relasi diri dengan orang lain. Akibatnya iman remaja sangat bergantung pada relasi dan pengaruh dari figur signifikan dari lingkungannya.

Tahapan iman dewasa sudah disertai dengan kemampuan menjalani proses sulit refleksi kritis terhadap identitas dan nilai-nilai yang dipegang oleh diri sendiri. Proses sulit ini dapat meliputi berbagai pertanyaan mengenai identitas diri jika terpisah dari lingkungan keluarga, sahabat atau keagamaan yang selama ini menjadi pegangan dan nilai-nilainya diwarisi (Fowler, 1991). Pada Tahapan iman matang di level selanjutnya, muncul kemampuan untuk mengambil sikap dengan berbagai perspektif berbeda yang paradoks. Tahap ini juga ditandai suatu keterbukaan berprinsip terhadap nilai-nilai dari budaya atau tradisi yang lain.

Mengembangkan instrumen untuk pengukuran Tahapan Iman Fowler secara empiris tampaknya menemui cukup banyak kesulitan, karena teori ini muncul bukan dari usaha awal empiris kuantitatif, melainkan dari penelitian interview kualitatif longitudinal. Parker (2006), misalnya, berpendapat bahwa FDI (Faith Development Interview) yang dipakai Fowler dan timnya sendiri yang bersifat wawancara semi-klinis untuk menanyakan pengalaman hidup yang signifikan dan pemaknaan yang mengikutinya, masih adalah alat terbaik yang paling tervalidasi untuk teori Fowler. Berbagai skala yang dicoba dibuat kemudian sering ditemukan tidak berkorelasi dengan hasil dari FDI (Parker, 2006). Salah satu instrumen yang dianggap cukup berhasil adalah yang dikembangkan oleh Heinz Streib (Streib, Hood \& Klein, 2010), karena berhasil juga divalidasi dengan FDI (Streib, Chen \& Hood, 2019).

Streib menyederhanakan Tahapan Iman menjadi yang disebut sebagai skema beragama (Religious Schema Scale / RSS), yang menggambarkan ragam sikap keagamaan. RSS yang disusun berusaha menangkap tiga skema beragama yang ada di tengah rentang Tahapan Iman Fowler: yaitu Mythic Literal, Individuative Reflective dan Conjunctive Faith. Dalam skema RSS yang dikembangkan Streib, ketiga ragam sikap ini disebut: (1) truths of texts and teachings (ttt), (2) fairness, tolerance, rational choice (ftr), dan (3) xenosophia, inter-religious dialog (xenos). Setiap skema berbeda ini berisi lima butir pertanyaan kuesioner dengan total pertanyaan sebanyak 15 butir (lihat Tabel 2). 
Tabel 2.

Versi Religious Schema Scale (RSS) dalam bahasa Indonesia

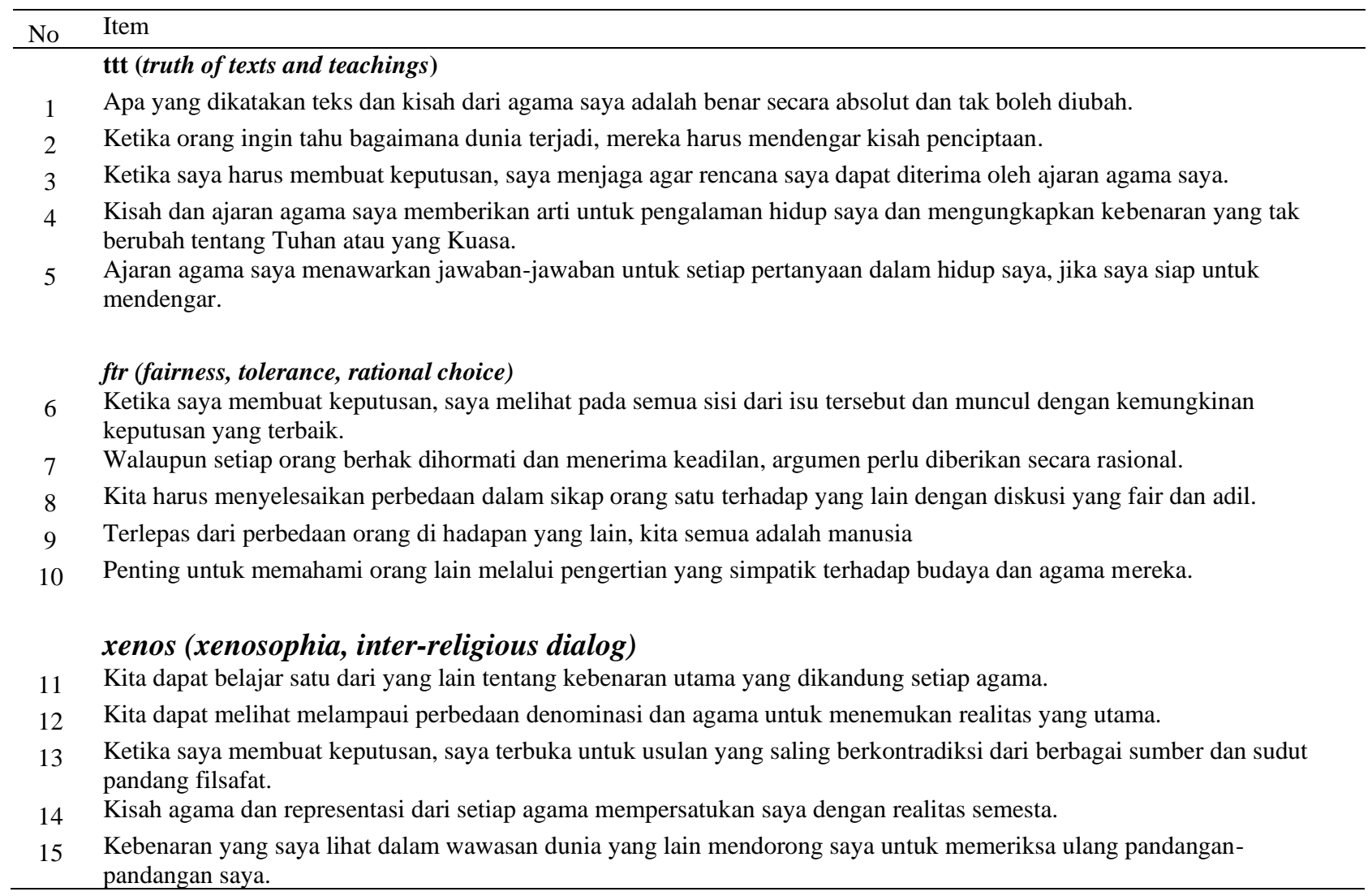

Untuk memperoleh gambaran perbandingan teori 4BDRS dan teori Tahapan Iman, perlu dilakukan review literatur dari berbagai negara dan bagaimana penerapan kedua teori ini di Indonesia. Fokus diskusi dan analisis terutama untuk mempertajam perbedaan, kekuatan/kelemahan dan kesimpulan berbagai penerapan kedua teori ini. Survey dan analisis ini juga diharapkan memerinci berbagai capaian riset sebelumnya, sehingga membuka gambaran potensi ruang penelitian berikutnya.

Berbagai artikel penting tentang teori 4BDRS dan Tahapan Iman Fowler, kesimpulan yang dihasilkan, serta berbagai penerapan penting dalam diskusi religiositas di Indonesia akan dianalisis dalam bagian berikut artikel ini.

\section{Kriteria Inklusi Data}

\section{METODE}

Mengingat banyaknya publikasi yang dapat ditemukan tentang studi psikologi agama atau religiositas, artikel ini memang tidak ditujukan melakukan analisis yang menyeluruh untuk semua publikasi yang ada. Tulisan ini hanya membatasi diri pada publikasi terkait teori 4BDRS atau teori Tahapan Iman yang cukup kompleks. Publikasi yang diambil adalah yang tidak bersifat hanya deskriptif pendahuluan, berinteraksi dengan konstruk psikologi lain, menampilkan data dari beberapa agama atau negara, dan atau berinteraksi dengan konsep dan telaah teologis yang lebih mendalam. Publikasi yang diambil juga meliputi berbagai artikel studi di negara lain dan Indonesia, sehingga 
dapat terbentuk gambaran perkembangan terkini dari kedua teori tersebut, yang akan sangat berguna untuk studi lebih lanjut ke depan.

Kriteria pemilihan artikel atau buku untuk disertakan dalam analisis di sini diharapkan akan meningkatkan potensi bergulirnya kumpulan penelitian psikologi agama di Indonesia dengan teori yang lebih sistematis dan tervalidasi baik. Untuk itu, artikel yang dipilih diambil yang lebih baru dari tahun 2000. Khusus untuk teori Tahapan Iman yang memang sudah berumur dan berasal dari tahun 1981, kriteria untuk pemilihan artikel dipilih lebih ketat karena jumlah artikel yang memang sangat banyak. Dalam hal ini, artikel yang berpotensi mendorong penelitian ke tingkat berikutnya dipilih dengan kriteria: (1) Mengandung pembahasan alat ukur (skala) yang tervalidasi dengan FDI, atau (2) Artikel survey yang membahas kritik terhadap teori Tahapan Iman, atau (3) Artikel atau buku yang membahas aplikasi, atau berinteraksi dengan konsep dan telaah teologis yang lebih mendalam.

Hasil penelitian dengan alat ukur yang sudah diuji di beberapa negara, dan dihubungkan dengan konstruk psikologi lain akan memperbesar kemungkinan memicu penelitian yang lebih solid. Pembaca akan dapat mengambil manfaat dan membuat perbandingan dengan banyak penelitian yang dilakukan sebelumnya, karena skala dan teori yang sudah tervalidasi dengan lebih baik dalam berbagai budaya, negara, agama dan konteks diskusi teologi agama.

\section{ANALISIS DAN HASIL}

Google Scholar digunakan untuk menemukan artikel terkait teori 4BDRS Saroglou atau teori Fowler. Hasilnya ditemukan lebih dari 48 ribu tulisan. Ini karena teori Fowler memang sudah cukup berumur sehingga memang sudah banyak memicu berbagai ulasan. Berdasarkan kriteria inklusi data yang telah dijelaskan pada bagian Metode, tersaring sebanyak 22 artikel (lihat Tabel 3). Untuk teori Tahapan Iman Fowler, alat ukur yang tervalidasi dengan FDI ditemukan adalah Religious Schema Scale (RSS) dari Streib \& Klein (2014), sehingga artikel yang terkait RSS-lah yang dipilih berdasarkan kriteria.

Tabel 3.

Perbandingan Studi 4BDRS dan Teori Fowler di Berbagai Negara dan Indonesia

\begin{tabular}{|c|c|c|c|c|}
\hline Sumber & Responden & Aplikasi Teori & Konstruk terkait & Hasil penting/menarik \\
\hline $\begin{array}{l}\text { Saroglou et al. } \\
(2020)\end{array}$ & $\begin{array}{l}3218 \\
\text { responden, } 14 \\
\text { negara, } 6 \text { agama }\end{array}$ & $\begin{array}{l}\text { CFA, Tinjauan antar } \\
\text { budaya/negara/agama } \\
\text { terhadap keagamaan } \\
\text { (4BDRS) }\end{array}$ & $\begin{array}{l}\text { Religious } \\
\text { fundamentalism, } \\
\text { Big five, } \\
\text { Existential Quest, } \\
\text { Need for closure, } \\
\text { Authoritarianism, } \\
\text { Life satisfaction }\end{array}$ & $\begin{array}{l}\text { Variasi 4BDRS antar } \\
\text { negara/agama/budaya/ dan relasi } \\
\text { dengan berbagai konstruk; CFA } \\
\text { menunjukkan dimensi invariance } \\
\text { dan configural invariance pada } 14 \\
\text { negara; Mean untuk Belonging } \\
\text { paling rendah; Behaving \& } \\
\text { Belonging terasosiasi dengan } \\
\text { fundamentalism; Bonding prediktif } \\
\text { untuk life satisfaction; Behaving } \\
\text { paling penting dalam Islam. }\end{array}$ \\
\hline
\end{tabular}

Dimitrova \& 1.982 responden Mesurement Espinosa (2017) dewasa, Mexico

Invariance Test

4BDRS untuk laki-

laki dan wanita
Satisfaction with Factorial structure dan measurement life (SWLS) invariance untuk laki-laki dan wanita; rata-rata keagamaan wanita lebih tinggi dari laki-laki; BDRS berkorelasi positif terhadap SWLS 


\section{Tabel 3.}

Perbandingan Studi 4BDRS dan Teori Fowler di Berbagai Negara dan Indonesia

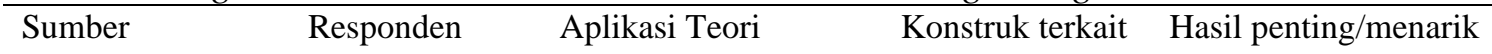

Aditya, Martoyo, 949 mahasiswa, et al. (2021) 9 universitas Jabodetabek
CFA, Mesurement Invariance Test 4BDRS untuk Islam dan Kristen, laki-laki dan wanita
Satisfaction with life (SWLS)

ATG-9, SWLS

Pengaruh moderasi attitude toward God (ATG-9) terhadap efek 4BDRS kepada well-being

Himawan (2020) 635 responden survey, 40 responden interview

Aditya, Ariela, 228 mahasiswa religious di Jabodetabek
Analisis pengaruh keagamaan (4BDRS), kesepian, dan wellbeing pada para lajang
Satisfaction with life (SWLS),

UCLA

Loneliness Scale (ULS-8)

Configural, metric, dan scalar invariance untuk Islam dan Kristen, laki-laki dan wanita; rata-rata lakilaki Muslim lebih tinggi keagamaannya dibanding wanita Muslim, sedangkan keagamaan pada laki-laki dan wanita Kristen tak ada perbedaan.

Semakin tinggi anger toward God, efek keagamaan terhadap wellbeing makin rendah.

Yang menikah mempunyai wellbeing lebih tinggi dan lebih tidak kesepian dibandingkan yang berpacaran dan yang lajang; yang berpacaran lebih tidak kesepian daripada yang lajang; keagamaan berefek signifikan positif pada wellbeing, dan tidak signifikan menurunkan perasaan kesepian pada yang berpacaran maupun lajang; Pemaknaan terhadap masa lajang meliputi: penantian untuk nikah, waktu untuk meningkatkan spiritualitas dan kegiatan luar rumah tangga, rentan terhadap dosa seksual

Martoyo, Aditya, 153 mahasiswa, T-test perbedaan et al. (2019) 2 universitas, Jabodetabek

160 mahasiswa, beberapa kota di Indonesia

Aditya, Sani et al. (2019)

Sani, Aditya, 331 mahasiswa Kristen dan Muslim,

keagamaan laki-laki dan wanita (4BDRS), dan perbedaan pergumulan agama/spiritual (R/SS)

Analisis regresi dimensi keagamaan (4BDRS) terhadap pergumulan agama/spiritual (R/SS)

et al. (2018)
T-test perbedaan keagamaan (4BDRS) laki-laki dan wanita pada mahasiswa Kristen dan Muslim
Religious/Spiritu Tak ada perbedaan signifikan al Struggle Scale keagamaan mahasiswa laki-laki dan (R/SS) wanita, namun pergumulan agama/spiritual laki-laki lebih tinggi dibanding wanita

Religious/Spiritu al Struggle Scale (R/SS)

Behaving dapat meningkatkan pergumulan agama/spiritual, sedangkan Bonding dan Believing mempunyai koefisien regresi negatif

Tak ada perbedaan signifikan kegamaan antara mahasiswa lakilaki dan wanita Kristen; mahasiswa laki-laki Muslim lebih tinggi keagamaannya dibanding mahasiswa wanita Muslim 
Tabel 3.

Perbandingan Studi 4BDRS dan Teori Fowler di Berbagai Negara dan Indonesia

\begin{tabular}{lllll}
\hline Sumber & Responden & Aplikasi Teori & Konstruk terkait & Hasil penting/menarik \\
\hline $\begin{array}{l}\text { Aditya, Sani } \\
\text { et al. (2020) }\end{array}$ & $\begin{array}{l}\text { 614 mahasiswa, } \\
\text { universitas } \\
\text { religious }\end{array}$ & $\begin{array}{l}\text { Analisis regresi } \\
\text { dimensi keagamaan } \\
\end{array}$ & $\begin{array}{l}\text { Satisfaction with } \\
\text { (4BDS) terhadap } \\
\text { well-being, mahasiswa }\end{array}$ & $\begin{array}{l}\text { Belonging meramalkan well-being } \\
\text { pada mahasiswa Muslim; Believing }\end{array}$ \\
& Muslim dan Kristen & & $\begin{array}{l}\text { dan Belonging meramalkan well- } \\
\text { being pada mahasiswa Kristen. } \\
\text { Behaving mempunyai nilai rata-rata } \\
\end{array}$ \\
& & & paling tinggi untuk mahasiswa \\
& & & Muslim, dan Believing yang \\
& & & tertinggi untuk mahasiswa Kristen.
\end{tabular}

Saputra, et al. (2017)

181 mahasiswa

Kristen, universitas di

Tangerang Agata \& Sidabutar
(2015)

88 remaja

Kristen di panti asuhan, usia 11-

20 tahun

Streib, Chen \& Hood (2019)

677 responden di US dan Jerman

340 remaja Jerman, usia 1225

Streib \& Klein (2014)

Susabda (2020)

Telaah teoretis dan teologi Kristen

Korelasi dimensi keagamaan (4BDRS) dengan well-being

Analisis regresi keagamaan (4BDRS) terhadap perasaan bersyukur (gratitude)

Analisis longitudinal dengan interview (FDI) dan Religious Schema Scale (RSS) untuk uji Tahapan Iman Fowler
Well-being

Believing dan Belonging berkorelasi dengan well-being pada mahasiswa Kristen

Gratitude

Questionnaire

Faith

Development Interview (FDI) longitudinal, Big Five (NEO-FFI)

Analisis teori Fowler dengan Religious Schema Scale (RSS) dan pengaruhnya pada sikap anti-Islam dan anti-Semitis

Teori Fowler menjadi bagian dari pendekatan integrasi teologi dan psikologi Kristen

Teori Fowler menjadi bagian penjelasan berbagai manifestasi
Stage 2 (ttt) memprediksi sikap prejudice anti-Islam dan antiSemitis; Peningkatan Tahapan Iman Fowler mengindikasikan penurunan prejudice

Teori Fowler menjelaskan perjumpaan antara apa yang diimani (teologi) dan psychological realities dalam jiwa; Telaah integrasi antara teologi dan psikologi yang terjadi dalam jiwa orang percaya

Berbagai gambaran manifestasi spesifik keimanan Kristen pada setiap Tahapan Iman Fowler
Sikap prejudice 
Tabel 3.

Perbandingan Studi 4BDRS dan Teori Fowler di Berbagai Negara dan Indonesia

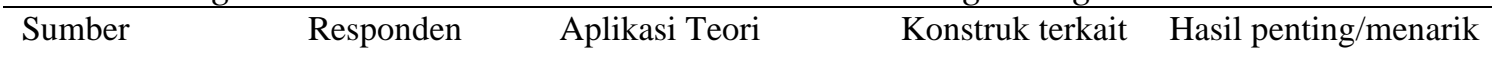

kehidupan iman yang

dapat bersifat

paradoks

Ardi et al. (2021) 761 mahasiswa, Analisis pengaruh Tolerance Scale 6 universitas, Tahapan Iman Fowler (Hook et al.)

usia 18-27 tahun dengan Religious

Schema Scale (RSS)

terhadap sikap toleran

terhadap agama

indigenous (asli

daerah) dan atheist

Tekke et al. (2015) 211 mahasiswa Analisis Tahapan Sunni Muslim, Malaysia

Iman Fowler (RSS) terhadap komitmen intelektual (ilm) dan openness to experience

Ilm scale, Opennes to experience, Quest, Attitude toward Islam, dll

Ghorbani et al. (2016)

398 mahasiswa (188 laki-laki Analisis Tahapan Iman Fowler (RSS) dan 210 wanita), seminari Iran dengan berbagai konstruk lain

320 mahasiswa (158 laki-laki dan 162 wanita) Hindu India

Analisis Tahapan

Kamble et al. (2014)

Coyle (2011)

Kritik teoretis terhadap pendekatan faith developmental Fowler Iman Fowler (RSS) dengan berbagai konstruk lain

Integrative Self Knowledge, Anxiety Depression, emphatic concern $\&$ perspective taking, dll

Openness to experience (OE), Quest, dll

Analisis teoretis terhadap kelemahan teori Fowler
Dimensi agama tak dapat memprediksi sikap intoleran terhadap agama asli daerah; kelompok Stage 2 (ttt) menunjukkan toleransi yang rendah terhadap atheist.

Bagian Doing dari ilm scale lebih berefek mediasi pada Religious Reflection thd TTT (Stage 2), sedangkan bagian Knowing dari ilm scale berefek mediasi lebih besar antara Religious Reflection pada FTR (Stage 4) dan Xenos (Stage 5); TTT tidak berkorelasi signifikan dengan openness (OE), sedangkan FTR dan Xenos berkorelasi positif dengan $\mathrm{OE}$

\section{FTR (Stage 4) menunjukkan} korelasi dan koefisien regresi positif paling tinggi terhadap Integrative Self Knowledge, emphatic concern dan perspective taking, dan negatif terbesar terhadap anxiety dan depression dibandingkan TTT (Stage 2) dan Xenos (Stage 5)

FTR (Stage 4) dan Xenos (Stage 5) menunjukkan korelasi yang lebih besar daripada TTT (stage 2) kepada OE dan Quest

Survey kritik terhadap teori Fowler, meliputi: Kritik terhadap konsep iman sebagai proses kemanusiaan universal, struktur hirarki tahapan dari teori, bias gender, dan ketertutupan pada postmodernisme. Kritik juga termasuk ketergantungan teori Fowler terhadap teori seperti Piaget yang fokus pada kemampuan rasionalitas obyektif (mengabaikan faktor pengalaman subyektif) dalam menjelaskan transisi antar tahapan.

Teori postformal (termasuk Fowler) yang mengandalkan konsep 
Tabel 3.

Perbandingan Studi 4BDRS dan Teori Fowler di Berbagai Negara dan Indonesia

\begin{tabular}{|c|c|c|c|c|}
\hline Sumber & Responden & Aplikasi Teori & Konstruk terkait & Hasil penting/menarik \\
\hline & $\begin{array}{l}\text { pendekatan } \\
\text { postformal } \\
\text { theory dalam } \\
\text { pemikiran orang } \\
\text { dewasa }\end{array}$ & teori postformal & & $\begin{array}{l}\text { kemampuan berpikir dialektika- } \\
\text { relativistik dikritisi sebagai ambigu } \\
\text { dan tidak jelas secara konseptual, dan } \\
\text { diusulkan untuk diganti dengan } \\
\text { konsep berpikir integratif } \\
\text { transformasional. }\end{array}$ \\
\hline Adiprasetya (2020) & $\begin{array}{l}\text { Kritik teoretis } \\
\text { terhadap } \\
\text { pendekatan faith } \\
\text { developmental } \\
\text { Fowler }\end{array}$ & $\begin{array}{l}\text { Komparasi model } \\
\text { tangga (teori Fowler) } \\
\text { dan model taman }\end{array}$ & - & $\begin{array}{l}\text { Kritik terhadap teori Fowler yang } \\
\text { homogen-normatif seperti "tangga" } \\
\text { dan bukan heterogen non-normatif } \\
\text { seperti taman yang menawarkan } \\
\text { spiritualitas yang multiplisitas } \\
\text { dengan banyak faktor yang } \\
\text { mempengaruhi. }\end{array}$ \\
\hline
\end{tabular}

\section{Analisis: Perkembangan Teori 4BDRS dan Aplikasi dalam Penelitian di Indonesia}

Hasil analisis (sebagaimana terlihat dalam Tabel 3) menunjukkan bahwa Teori 4-Dimensi Keagamaan Saroglou telah teruji di belasan negara Eropa, Asia dan Amerika, termasuk Taiwan, Turki dan Meksiko (Saroglou et al., 2020; Dimitrova \& Espinosa, 2017). Untuk kasus Indonesia sendiri, 4BDRS telah diuji kestabilan konstruknya untuk komunitas Islam dan Kristen, dan antara sampel lakilaki dan wanita (Aditya et al., 2021). Dimensi keagamaan dalam 4BDRS telah diteliti dengan berbagai konstruk lain yang meliputi: Well-being (SWLS) (Aditya, Ariela, et al., 2020; Saputra, et al., 2017; Himawan, 2020), Religious/Spiritual Struggle (R/SS) (Martoyo, Aditya, et al., 2019; Aditya, Sani et al., 2019), Anger toward God (ATG) (Aditya, Ariela, et al., 2020), Big Five (Saroglou et al., 2020), Fundamentalisme (Saroglou et al., 2020), Gratitude (Agata \& Sidabutar, 2015), dan Loneliness (Himawan, 2020).

Walaupun penelitian psikologi agama di Indonesia masih sering ditemukan tidak berbasis teori yang teruji (El Hafiz \& Aditya, 2021), namun dari kajian ini menemukan ada 9 artikel studi menggunakan 4BDRS dan 4 artikel studi menggunakan teori Fowler yang dilakukan di Indonesia. Beberapa dimensi agama seperti Belonging dan Believing ditemukan berhubungan dan dapat memprediksi well-being (Saputra, et al., 2017). Keagamaan antara laki-laki dan wanita Kristen di Indonesia juga tidak menunjukkan perbedaan signifikan (Aditya, Martoyo, et al., 2021; Sani, Aditya, et al., 2018; Martoyo, Aditya, et al., 2019). Di lain pihak laki-laki Muslim menunjukkan keagamaan lebih tinggi dibanding wanita Muslim (Sani, Aditya, et al., 2018). Dimensi Behaving tampak dominan untuk umat Islam (Aditya, Sani et al., 2020) dan prediktif terhadap gratitude pada kelompok Kristen (Agata \& Sidabutar, 2015). Pengaruh positif keagamaan terhadap well-being dapat turun akibat anger toward God (Aditya, Ariela, et al., 2020). Walaupun ditemukan berkorelasi positif pada well-being, keagamaan tidak berkontribusi menurunkan kesepian pada yang lajang (Himawan, 2020).

Dari data Tabel 3, tampak bahwa teori 4BDRS telah teruji dan tervalidasi di belasan negara. Penelitian dengan 4BDRS juga menunjukkan variasi: Dari penelitian yang menggunakan keagamaan sebagai variabel besar untuk mencari hubungan atau pengaruhnya terhadap variabel lain, atau mencermati dimensi tertentu atau perbedaan dimensi (Believing, Bonding, Behavior, Belonging) terhadap variabel lain pada agama tertentu, ataupun studi efek gender pada keagamaan. Dan karena 
4BDRS sudah melewati uji faktorial dan uji invariance (Aditya et al., 2021), maka dapat dipastikan struktur skalanya stabil untuk digunakan membandingkan agama atau gender, paling tidak, sejauh ini untuk agama Islam dan Kristen. Uji faktorial dan invariance untuk agama lain masih harus dilakukan untuk memperluas kemungkinan penelitian dengan skala 4BDRS di Indonesia.

\section{Analisis: Perkembangan Teori Fowler dan Aplikasi dalam Penelitian di Indonesia}

Seperti disebutkan sebelumnya, terdapat 4 artikel dari Indonesia terkait teori Fowler. Namun demikian hanya satu artikel yang menggunakan skala Religious Schema Scale (RSS) untuk studi kuantitatif (Ardi et al., 2021). Ini memperkuat indikasi bahwa teori Fowler memang tampaknya mengalami kesulitan untuk diterjemahkan ke dalam skala untuk penelitian kuantitatif. Parker (2006) yang melakukan survey pada beberapa skala untuk teori Fowler masih terpaksa menyimpulkan bahwa alat terbaik tetap masih FDI (Faith Development Interview) yang dipakai Fowler sendiri, namun yang memakan waktu sangat panjang untuk digunakan.

Angin segar datang dari Streib \& Klein (2014) yang mengembangkan Religious Schema Scale (RSS) untuk melakukan pengukuran kuantitatif berdasarkan tipe beragama dari teori Fowler. RSS sudah berhasil juga divalidasi dengan FDI dan juga diuji korelasinya dengan Big Five (Streib, Chen \& Hood, 2019). Selain itu, dari Tabel 3, tercatat ada 3 penelitian dengan menggunakan RSS di Malaysia, Iran dan India yang melibatkan berbagai konstruk psikologi/variabel lain seperti openness, Quest, dan anxiety (Kamble et al., 2014; Tekke et al., 2015; Ghorbani et al., 2016).

Penggunaan Religious Schema Scale (RSS) tidak dapat secara langsung menunjukkan Tahapan Iman Fowler (Streib, Chen \& Hood, 2019). Berdasarkan pengujian dengan interview longitudinal (FDI) yang dilakukannya, Streib mengusulkan untuk memperhatikan ketiga dimensi dalam RSS (ttt, ftr dan xenos) sekaligus untuk penentuan tipologi Fowler sebagai berikut:

(a) Skor tertinggi secara proporsional pada subskala RSS ttt, bersamaan dengan skor terendah secara proporsional pada subskala RSS xenos, dan skor terendah secara proporsional pada subskala RSS ftr mencirikan Fowler's Stage - Mythic Literal;

(b) Tahap 3 (Fowler) - Synthetic Conventional - memiliki profil yang paling tidak menonjol dan paling tidak koheren dalam subskala RSS;

(c) Skor terendah secara proporsional pada ttt adalah karakteristik Tahap 4 Fowler (IndividuativeReflective);

(d) Kecocokan tertinggi proporsional dengan xenos adalah karakteristik Tahap 5 Fowler - Conjunctive Faith.

Kerumitan konstruksi RSS yang tidak secara langsung menunjuk pada Tahapan Fowler tampaknya mengisyaratkan semacam kompleksitas dari teorinya, yang juga sudah menuai berbagai kritik. Pada kenyataannya setiap orang tidak menunjukkan hanya satu "gaya" beragama saja, melainkan menunjukkan spektrum yang mencakup ketiga dimensi dari RSS. Sehingga menangkap pola tahapan Fowler tertentu harus dilakukan dengan memperhatikan ketiga dimensi RSS secara bersamaan.

Walaupun menyimpan kerumitan tertentu, teori Fowler yang terkristal dalam RSS tampaknya juga berhasil menunjukkan berbagai pola yang terobservasi baik terkait openness to experience dan Quest, yang dapat memberikan indikasi sikap beragama tertentu seperti prejudice dan fundamentalisme (Streib \& Klein, 2014; Ardi et al., 2021).

Hasil analisis juga menemukan beberapa artikel mengkritik teori Fowler (Coyle, 2011; Kallio, 2011), yang dapat berguna memberikan gambaran terhadap kelemahan teori tersebut. Coyle (2011) 
melakukan survey terhadap berbagai bentuk kritik ini, yang meliputi: kritik terhadap konsep iman sebagai proses kemanusiaan universal, struktur hirarki tahapan dari teori, bias gender, dan ketertutupan pada postmodernisme. Kritik semacam ini juga memicu perkembangan skala Fowler yang tidak mengasumsikan tahapan, melainkan jenis gaya beragama yang berbeda (Streib \& Klein, 2014).

Kritik lain yang juga sering dilancarkan terhadap teori Fowler berkaitan dengan konsep pemikiran postformal yang muncul dalam teori Fowler. Teori perkembangan kognitif Piaget menjelaskan tahap formal operational (umur 12 tahun) sebagai tahapan berpikir abstrak yang tertinggi, sedangkan teori Fowler tampaknya mengusulkan adanya tahap postformal untuk proses berpikir orang dewasa dalam teori perkembangan imannya. Kritik terhadap pemikiran postformal ini contohnya adalah yang diajukan Kallio (2011) yang mengatakan bahwa teori postformal ambigu dan tidak jelas. Kallio sendiri mengusulkan untuk menggunakan pemahaman berpikir “integrasi” sebagai gantinya (Kallio, 2011).

Khusus di Indonesia, teori Fowler menarik perhatian Susabda (2002) yang mengadaptasinya untuk menjelaskan fenomena manifestasi keimanan pada umat Kristen di Indonesia, dan juga untuk praktik "integrasi”" teologi dan psikologi (Lihat Tabel 3). Walaupun Susabda dan Kallio tampaknya memakai istilah "integrasi" dengan cara berbeda, sangat menarik bahwa kata tersebut sama-sama diasosiasikan kepada sesuatu yang dianggap ideal setelah bergulat dengan ide Tahapan Iman Fowler.

Selain itu, tampak bahwa teori Fowler dimanfaatkan di Indonesia untuk menjelaskan berbagai fenomena yang muncul dalam komunitas agama. Susabda (2020) memanfaatkan teori Fowler untuk mendorong kehidupan agama yang disebut lebih integratif. Susabda menjelaskan bahwa persoalan integrasi bukan pada sekedar masalah teori dan pendekatan tetapi berfokus pada diri orang tersebut (integrator) yang menghidupi imannya di tengah kesadaran akan jiwa dan pengenalan dirinya. Penjelasan Susabda (2002) membuat teori Fowler menjadi masuk akal ketika orang bergumul dan mengalami pertumbuhan. Kerohanian manusia tidak serta-merta menjadi hebat, tetapi butuh proses untuk membuka diri dan memberikan peluang iman bekerja dalam dirinya.

Berbagai artikel yang ada di Tabel 3 juga menunjukkan tendensi peluang aplikasi teori Fowler yang senada. Tahapan iman, atau paling sedikit gaya beragama yang berbeda, diharapkan dapat menjelaskan sikap yang berbeda juga dalam hal prejudice dan fundamentalisme agama, misalnya. Semakin ia naik tingkat (atau mengembangkan gaya beragama yang berbeda), maka ada harapan orang tersebut menjadi lebih terbuka/kurang prejudis (Streib \& Klein, 2014), ada keterbukaan (Tekke et.al. 2015), dan toleran terhadap yang berbeda bahkan ateis (Ardi et.al. 2021). Kritik terhadap teori Fowler di Indonesia juga muncul terhadap konsep struktur tangga yang homogen, yang dianggap kurang mengakomodasi heterogenitas pengalaman beragama (Adiprasetya, 2020).

\section{DISKUSI}

\section{Perbedaan dan Kekuatan/Kelemahan Teori 4BDRS vs Fowler}

Teori 4-Dimensi Keagamaan 4BDRS dan teori Tahapan Iman sama-sama menyediakan pendekatan untuk menangkap fenomena psikologi agama. Keduanya tidak terikat terhadap partikularitas agama tertentu, melainkan berusaha menangkap fenomena psikologis keagamaan yang secara universal ditunjukkan dalam berbagai agama. Dengan demikian teori 4BDRS dan teori Fowler menawarkan keuntungan untuk aplikasi yang lebih luas dan perbandingan fenomena dalam berbagai agama, budaya dan tradisi yang berbeda. 
Teori 4BDRS berfungsi seperti alat pengukur frekuensi yang mencoba mengukur komponen frekuensi yang muncul atau dominan pada "lagu" keagamaan tertentu. Ke-empat dimensi kognitif, emosional, moral dan sosial yang ditangkap dalam teori 4BDRS sering muncul juga terkristalisasi dalam berbagai tradisi keagamaan. Tradisi Kristen Metodis misalnya mengusung 4 pilar untuk penghayatan iman (Wesleyan Quadrilateral): kitab suci, pengalaman, rasio dan tradisi (lahir dari komunitas orang percaya). Walaupun tidak tepat sejajar dengan komponen 4BDRS, namun dapat terlihat dengan cepat berbagai hal yang paralel. Tradisi Islam misalnya memahami akidah, ibadah, akhlak dan kesatuan umat sebagai bagian dari penghayatan imannya. Dalam membicarakan praktik keagamaan, banyak teolog yang menekankan orthodoxy (doktrin yang benar), orthopathy (emosi yang baik), orthopraxy (perilaku yang baik), dan kehidupan yang baik bersama umat percaya. Sehingga, teori 4BDRS menangkap secara lebih lengkap dimensi penghayatan keagamaan dibanding banyak instrumen lain yang hanya satu dimensi.

Teori 4BDRS menangkap fenomena keagamaan secara multidimensi, tetapi tidak mengasumsikan suatu perkembangan spiritualitas ke tahapan struktur jiwa yang lebih tinggi seperti yang ditawarkan teori Fowler. Walaupun teori Fowler menarik untuk menjelaskan proses pertumbuhan spiritual, namun tampaknya pembuktian empiris teori Fowler cukup sulit untuk dilakukan. Penggunaan RSS dari Streib, walaupun cukup berhasil menunjukkan berbagai fenomena yang mengkonfirmasi bahwa Tahap 2 dari Fowler (ttt) dapat tumbuh ke tahap yang lebih tinggi (ftr atau xenos) (Streib, Chen \& Hood, 2019), namun penggunaan RSS tidak dapat secara langsung menunjuk kepada tipologi Fowler hanya dengan satu dimensi RSS tertentu saja.

Aplikasi teori Fowler secara empiris di Indonesia tampaknya lebih terbatas daripada aplikasi 4BDRS (walaupun banyak penelitian 4BDRS di Indonesia berasal dari grup peneliti yang sama). Kuesioner 4BDRS tampaknya juga lebih mudah dipakai untuk berbagai penelitian dengan konstruk lain. Walaupun begitu, konsep pertumbuhan rohani selalu menarik untuk dikaji karena terkait dengan berbagai usaha pendidikan dan pembinaan kerohanian. Sehingga, teori yang berfungsi baik dan dilengkapi dengan instrumen yang teruji untuk pengukuran pertumbuhan rohani juga terus dibutuhkan.

Pendekatan Yakub Susabda mengadaptasi teori Fowler untuk Pendidikan teologi menunjukkan suatu intuisi bahwa pertumbuhan rohani yang real selalu terkait aspek relasional dan struktur kejiwaan, yang menjadi wadah manifestasi keimanan yang dapat muncul secara paradoks (Susabda, 2002). Ini bertentangan dengan banyak pendekatan pendidikan keagamaan yang bernuansa mencekoki dan menghapal yang sering terbukti gagal untuk menghasilkan pertumbuhan spiritual. Teori Fowler dianggap berpotensi menjawab keresahan akibat banyaknya kegagalan pendidikan kerohanian dan dapat menunjuk kepada jalan yang lebih baik.

Aplikasi teori BDRS dalam berbagai penelitian tampaknya terkait dengan psikologi positif dan banyak dihubungkan dengan well-being dan stress. Teori BDRS juga dihubungkan dengan berbagai konstruk lain, termasuk: Anger toward God, Big Five, Fundamentalisme, Gratitude, dan Loneliness. Sedangkan teori Fowler, karena menyediakan gambaran pertumbuhan rohani, sering dikaitkan dengan fenomena seperti prejudice dan fundamentalisme yang diharapkan dapat surut dengan tingkat pertumbuhan spiritual yang lebih tinggi. Berbagai penelitian juga telah menghubungkan teori Tahapan Iman dengan openness, Quest, dan anxiety.

Bergelut dalam bidang psikologi agama dapat berjumpa dengan sikap kecurigaan dan bermusuhan terhadap bidang psikologi atau terhadap bidang agama (Susabda, 2020). Peneliti dari 
bidang agama dapat mencurigai bidang psikologi yang mempunyai sejarah tokoh-tokoh yang ateis dan memusuhi agama. Sebaliknya, dari bidang psikologi bisa juga ada kecurigaan terhadap berbagai penjelasan yang berbau agama yang dianggap tidak empiris dan tidak ilmiah. Aplikasi teori seperti 4BDRS dan teori Fowler dapat membuat ruang tunda, sehingga fenomena psikologis dapat diteliti dan didiskusikan terlepas dari - dan tanpa mengganggu - konten sistem agama tertentu. Di sisi yang lain, menyikapi realitas psikologi secara serius dapat menghindarkan seseorang dari pola pikir agamawi yang simplistis, yang tidak menyadari kompleksitas gejolak kejiwaan manusia (mis: pikiran bahwa seseorang yang sudah berpikiran agamawi yang benar pasti akan beres juga hidupnya).

Susabda (2020) mengomentari kerumitan mendekati problem pergulatan jiwa dan iman ini demikian:

Pergumulan utama iman Kristen, bukan hanya masalah bagaimana berteologi dan memahami kebenaran firman Allah, seperti yang sudah diupayakan selama ratusan tahun oleh gereja dan sekolah-sekolah teologi. Sebab masalah yang sesungguhnya dalam iman Kristen adalah masalah integrasi, yaitu masalah perjumpaan integratif antara kebenaran firman Allah (teologi) dan psychological realities (realitas psikologis) dalam jiwa manusia (hal. 25-26).

Jika benar, maka memang dibutuhkan pendekatan teoretis yang integratif antara psikologi dan teologi. Pada saat yang bersamaan diperlukan juga ruang tunda untuk diskusi yang produktif ketika asumsiasumsi agama/teologi "terpeleset” tersandung realitas psikologis.

\section{REKOMENDASI DAN LIMITASI}

\section{Rekomendasi}

Teori 4BDRS sudah teruji dan diterapkan untuk penelitian keagamaan multidimensi yang melibatkan banyak negara, budaya, agama dan konstruk psikologis. Kestabilan struktur konstruknya juga telah diuji dalam berbagai konteks, dan di Indonesia sudah ditunjukkan stabil untuk laki-laki dan wanita dalam komunitas Islam dan Kristen. Masih terbuka peluang penelitian untuk menguji kestabilan konstruk 4BDRS dalam agama Hindu dan Budha, serta keunikan dimensi agama tersebut dan relasinya terhadap well-being atau variabel lain.

Belum banyak penerapan pengukuran teori Fowler di Indonesia, dan aplikasi RSS di Indonesia masih perlu dikonfirmasi dengan berbagai uji. Penerapan teori Fowler lewat RSS untuk melihat relasi pertumbuhan iman dengan well-being bisa cukup menarik, karena bisa saja perjalanan ke tahap iman yang lebih tinggi justru melewati berbagai krisis yang menimbulkan banyak keresahan yang dapat berakibat turunnya well-being.

Kerumitan dan komplikasi penggunaan RSS yang tidak secara langsung menunjuk pada tahapan Fowler berpotensi untuk disederhanakan jika ditemukan variabel lain yang memang erat berkorelasi dan prediktif terhadap Tahap Iman Fowler. Dari berbagai penelitian dalam Tabel 3, tampaknya variabel openness to experience dan konstruk Quest, berpotensi indikatif terhadap pertumbuhan iman dalam kerangka teori Fowler. Ini juga perlu pengujian lebih lanjut yang sistematis dalam konteks Indonesia.

Penggabungan teori 4BDRS dan teori Fowler juga menyimpan potensi pemahaman yang lebih baik tentang kombinasi dimensi keagamaan yang kondusif untuk pertumbuhan iman. Jika teori 
4BDRS diteliti bersama teori Fowler, maka dapat terlihat misalnya dimensi religiositas mana (kognitif, afektif, behavior, komunal) yang akan lebih berpengaruh pada perubahan Tahapan Iman Fowler. Juga ada kemungkinan bahwa komunitas agama yang berbeda akan menunjukkan variasi dimensi agama yang khas untuk pertumbuhan spiritual.

Teori Fowler juga menerima kritik sebagai bias terhadap budaya tertentu (Tekke et al., 2015; Ghorbani et al., 2016; Kamble et al., 2014). Ini memerlukan kehati-hatian tersendiri dalam melakukan adaptasi teoretis terhadap konteks budaya Timur seperti Indonesia. Ada kemungkinan bahwa fenomena kedewasaan rohani/spiritual tidak sama persis antara budaya Barat dan Timur, misalnya individu yang dianggap memiliki individualitas yang lebih indenpenden akan dianggap lebih dewasa di budaya Barat. Apakah budaya Timur yang lebih komunal akan mempunyai pemaknaan yang sama atau konsep kedewasaan tersebut harus mengalami modifikasi? Berbagai pertanyaan serupa perlu diuji lebih lanjut dalam berbagai penelitian.

\section{Limitasi}

Survey literatur yang dilakukan penulis di sini tidaklah menyeluruh, dan memang mengabaikan berbagai artikel yang tidak memenuhi kriteria yang dipilih. Sehingga, gambaran yang diberikan di sini juga jauh dari lengkap, namun diharapkan bermanfaat untuk peneliti yang ingin melangkah masuk ke bidang psikologi agama.

Terdapat usaha-usaha lain untuk mengembangkan instrumen pengukuran teori Fowler yang tidak dimasukkan dalam artikel ini (lihat Parker, 2006), yaitu skala yang belum berhasil divalidasi dengan FDI. Tidak tertutup kemungkinan skala-skala tersebut di kemudian hari dapat divalidasi juga. Namun mengingat proses validasi ini membutuhkan proses interview longitudinal yang panjang, maka lebih menguntungkan menggunakan skala yang sudah tervalidasi seperti dari Streib, Chen \& Hood (2019).

\section{REFERENSI}

Adiprasetya, J. (2020). Dari tangga ke taman: Multiplisitas pertumbuhan iman dan implikasinya bagi karya pedagogis, pastoral, dan liturgis gereja. Dunamis: Jurnal Teologi dan Pendidikan Kristiani, 4 (2), 127-142. https://doi.org/10.30648/dun.v4i2.232

Aditya, Y., Sani, R., Martoyo, I., \& Pramono, R. (2019). Can religiousness be associated with religious and spiritual struggles? Advances in Social Science, Education and Humanities Research, 229, 1092-1100. https:// doi.org/10.2991/iciap-18.2019.91

Aditya, Y., Sani, R., Martoyo, I., \& Pramono, R. (2020). Predicting well-being from different dimensions of religiousness. In Proceeding of the 3rd International Conference on Psychology in Health, Educational, Social, and Organizational Settings (ICP-HESOS),458-463, Surabaya, Indonesia, 2018. https:// doi.org/10.5220/0008590804580463

Aditya, Y., Ariela, J., Martoyo, I., \& Pramono, R. (2020). Does Anger Toward God Moderate the Relationship Between Religiousness and Well-Being?. Roczniki Psychologiczne, 23(4), 375384.

Aditya, Y., Martoyo, I., Nurcahyo, F. A., Ariela, J., \& Pramono, R. (2021). Factorial structure of the four basic dimensions of religiousness (4-BDRS) among Muslim and Christian college students 
in Indonesia. Cogent Psychology, 8(1), 1974680.

Agata, W., \& Sidabutar, F. (2015). Pengaruh religiusitas terhadap gratitude pada remaja yang tinggal di panti asuhan Kristen. Jurnal Psikologi Ulayat, 2(1), 348-363. https://doi.org/10.24854/jpu27

Ardi, R., Tobing, D. H., Agustina, G. N., Iswahyudi, A. F., \& Budiarti, D. (2021). Religious schema and tolerance towards alienated groups in Indonesia. Heliyon, 7(7), e07603.

Coyle, A. (2011). Critical responses to faith development theory: A useful agenda for change?. Archive for the Psychology of Religion, 33(3), 281-298.

Dimitrova, R., \& del Carmen Domínguez Espinosa, A. (2017). Factorial structure and measurement invariance of the Four Basic Dimensions of Religiousness Scale among Mexican males and females. Psychology of Religion and Spirituality, 9(2), 231.

El Hafiz, S., \& Aditya, Y. (2021). Kajian Literatur Sistematis Penelitian Religiusitas di Indonesia: Istilah, Definisi, Pengukuran, Hasil Kajian, serta Rekomendasi. Indonesian Journal for The Psychology of Religion, 1(1), 1-22.

Fowler, J. W. (1981). Stages of faith: The psychology of human development and the quest for meaning Harper \& Row. San Francisco.

Fowler, J. W. (1991). Stages in faith consciousness. New Directions for Child and Adolescent Development, 1991(52), 27-45.

Ghorbani, N., Watson, P. J., Amirbeigi, M., \& Chen, Z. J. (2016). Religious schema within a Muslim ideological surround: Religious and psychological adjustment in Iran. Archive for the Psychology of Religion, 38(3), 253-277.

Himawan, K. K. (2020). Menikah adalah ibadah: Peran agama dalam mengkonstruksi pengalaman melajang di Indonesia. Jurnal Studi Pemuda, 9(2), 120-135.

Kallio, E. (2011). Integrative thinking is the key: An evaluation of current research into the development of adult thinking. Theory \& Psychology, 21(6), 785-801.

Kamble, S. V., Watson, P. J., Marigoudar, S., \& Chen, Z. (2014). Varieties of openness and religious commitment in India: Relationships of attitudes toward Hinduism, Hindu religious reflection, and religious schema. Archive for the Psychology of Religion, 36(2), 172-198.

Leak, G. K., Loucks, A. A., \& Bowlin, P. (1999). Development and initial validation of an objective measure of faith development. The International Journal for the Psychology of Religion, 9(2), 105-124.

Martoyo, I., Aditya, Y., Sani, R., \& Pramono, R. (2019). Religious and spiritual struggle among Indonesian students: Who struggle more, males or females? Advances in Social Science, Education and Humanities Research, 229, 329-337. https://doi.org/10.2991/ iciap-18.2019.28

Parker, S. (2006). Measuring faith development. Journal of Psychology and Theology, 34(4), 337-348.

Poushter, J., Fetterolf, J., \& Tamir, C. (2019). A changing world: Global views on diversity, gender equality, family life and the importance of religion. Pew Research Center, 44.

Sani, R., Aditya, Y., Martoyo, I., \& Pramono, R. (2018). Multidimensional Religiousness among 
Indonesia Journal for The Psychology of Religion (2021), 1(2), 79-96

Christian and Muslim students: Are there gender differences in Indonesia. In Proceedings of the 3rd International Conference on Social Sciences, Laws, Arts and Humanities (BINUS-JIC 2018) (pp. 609-614).

Saputra, A., Goei, Y. A., \& Lanawati, S. (2017). Hubungan Believing dan Belonging sebagai dimensi religiusitas dengan lima dimensi well-being pada mahasiswa di Tangerang. Jurnal Psikologi Ulayat, 3(1), 7-17. https:// doi.org/10.24854/jpu12016-52

Saroglou, V. (2011). Believing, bonding, behaving, and belonging: The big four religious dimensions and cultural variation. Journal of Cross-Cultural Psychology, 42(8), 1320-1340.

Saroglou, V., Clobert, M., Cohen, A. B., Johnson, K. A., Ladd, K. L., Van Pachterbeke, M., ... \& Tapia Valladares, J. (2020). Believing, bonding, behaving, and belonging: The cognitive, emotional, moral, and social dimensions of religiousness across cultures. Journal of CrossCultural Psychology, 51(7-8), 551-575.

Streib, H., Hood Jr, R. W., \& Klein, C. (2010). The Religious Schema Scale: Construction and initial validation of a quantitative measure for religious styles. The International Journal for the Psychology of Religion, 20(3), 151-172.

Streib, H., \& Klein, C. (2014). Religious styles predict interreligious prejudice: A study of German adolescents with the Religious Schema Scale. International Journal for the Psychology of Religion, 24(2), 151-163.

Streib, H., Chen, Z. J., \& Hood Jr, R. W. (2019). Categorizing people by their preference for religious styles: Four types derived from evaluation of Faith Development Interviews. The International Journal for the Psychology of Religion, 30(2), 112-127.

Tekke, M., Watson, P. J., İsmail, N. A. H., \& Chen, Z. (2015). Muslim religious openness and ilm: Relationships with Islamic religious reflection, religious schema, and religious commitments in Malaysia. Archive for the Psychology of Religion, 37(3), 295-320.

Storr, A. (2001). Freud: A very short introduction. OUP Oxford.

Susabda, Y. B. (2002). Mengenal dan bergaul dengan Allah. Gospel Press.

Susabda, Y. B. (2020). Mengalami Kemenangan Iman: Integrasi Teologi \& Psikologi. Literatur Perkantas. 
